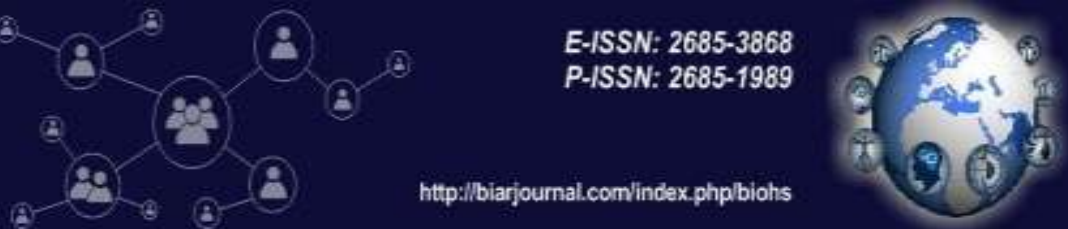

\title{
Implementation of Quintuple Helix in the Development and Improvement of SMEs Competitiveness in Banyuwangi Regency
}

\author{
Herdiana Dyah Susanti ${ }^{1 *}$, Dian AriefPradana ${ }^{2}$ \\ 1,2Faculty of Engineering, Universitas 17 Agustus 1945 Surabaya, Indonesia \\ Email: mailto:herdianadyahs@gmail.com,mailto:dianariefpradana.dap@gmail.com
}

\begin{abstract}
:
Innovation is an interactive result that involves various types of actors based on the helix concept where each actor contributes according to its role. University, Industry, Government, Civil Society and media and culture-based society, society and natural environment in the concept of quintuple helix. This study aims to (1) Demonstrate the relationship between quintuple helix in developing SMEs competitiveness, (2) Effectiveness of the application of quintuple helix in developing SMEs competitiveness. This research is almost the same as experimental research with the pre-test - post-test results of the application of quintuple helix at SMEs in Banyuwangi Regency. The results of this study show the role of the University, Industry, Government, Civil Society as well as media and culture-based society, society and the natural environment in the concept of quintuple helix can improve the competitiveness of $S M E s$, enhance the capabilities of HR, improve the quality, and competitiveness of products produced by SMEs.
\end{abstract}

Keywords:

Quantiple helix; Competitiveness; SMEs

\section{Introduction}

Every human life always depends on social life and the economic ecosystem in life. Therefore, in perceiving life not only economic expenditure but also changes in social and environmental life. Interrelationships between people, businesses, organizations, social groups, governments, and other groups are very complex and produce unlimited variations (Berg, 2012).

The competitiveness and economic growth of a country must be supported by innovation where the helix concept is known as the creator of innovation. Innovation is an interactive result that involves various types of actors based on the helix concept where each actor contributes according to its role. Triple helix Etzkowitz and Leydesdorff (Etzkowitz \& Leydesdorff, 2000) is a collaboration of three sectors namely academic, government, and industry. Social development interactions are still at an early stage in Pakistan (Etzkowitz \& Zhou, 2007).

Recently emerging research in this field is to promote entrepreneurship towards business creation. In addition, regional Triple Helix innovation is also a function of academic goals and objectives, trust between universities, industry and government and the strength of local organizing and initiation abilities. However, the abundance of knowledge is increasingly occurring through commercialization of research results on campus, regardless of social or academic differences (Etzkowitz \& Zhou, 2007). 
The Quintuple Helix model is based on the Triple Helix and Quadruple Helix models and adds a natural environment as the fifth helix. Quintuple Helix is a Penta helix model, where the environment or natural environment represents the fifth helix (Carayannis \& Campbell, 2010). University, Industry, Government, Civil Society and media and culture-based society, society and natural environment in the concept of quintuple helix (Praswati, 2017). Research (Carayannis \& Campbell, 2010) explained that quintuple helix plays a role in sustainable economics, for example in eco- innovation and eco-entrepreneurship.

This model is applied to one of the SMEs in Banyuwangi Regency which produces a product with Moringa as a base ingredient. This product is produced because it contains high nutritional value and has several medicinal substances that can be nutritional and medical alternatives even though it is still socially neglected (Brilhante et al., 2017). In this study, the role of each sector involved in quintuple helix in the development of SMEs will be examined. One of them is Eco-entrepreneurship which is implemented to one of the SMEs in Banyuwangi Regency, namely by CV. Kelorwangi Berkah Melimpah.

CV. Kelorwangi Berkah Melimpah has applied the Quintuple helix concept in developing its business. CV. Kelorwangi Berkah Melimpah have involved universities, industry, government, civil society as well as media and culture-based community, society and natural environment. The role of each sector in the Quintuple helix model supports the formation of ecology, knowledge, and innovation, creating synergies between the economy, society and democracy (Carayannis, Barth, \& Campbell, 2012). The purpose of this study is to show the relationship and effectiveness of the application of quintuple helix in the development of SMEs competitiveness. So the hypothesis in this study are there is no difference in average test scores between before and after the training provided by academics and government funding and there is a difference in average test scores between before and after training provided by academics and government.

\section{Review of Literatures}

\subsection{Small Medium Enterprises}

UU No. 20 tahun 2008 (Undang-Undang No 20 Tabun 2008, 2008) concerning Micro, Small and Medium Enterprises (SMEs) states that SMEs are businesses carried out by individuals in the form of economic businesses that meet the SMEs criteria as in the constitution. SMEs must become priorities in political policy as support for the growth and development of SMEs competitiveness (Abrhám, Bilan, Krauchenia, \& Strielkowski, 2015), (Pletnev \& Barkhatov, 2016), (Barkhatov, Pletnev, \& Campa, 2016), (Varanavicius, V., Navikaite, A., Bilan, Y., \& Strielkowski, 2017). That is because SMEs play a role in developing sustainable economic, therefore SMEs regionally are an important part of a country's economic development. SMEs also help shape the economy, increase investment, create jobs, and various other economic potentials (Janda, Rausser, \& Strielkowski, 2013), (Koudelková \& Svobodová, 2014), (Belás, Bilan, Demjan, \& Sipko, 2015), (Simionescu, Bilan, Smrčka, \& Vincúrová, 2017).

SMEs have so many problems that can hamper the development of SMEs performance, such as limited marketing technology, lack of supervision standards, Human Resources (HR) which have low motivation and competence (Wahyuningrum, Sukmawati, \& Kartika, 2014). The parameters and variables of modeling in the analysis of SMES innovation systems according to (Trisnawati, 2016) include marketing techniques and market research, limited technology and human resources to operate new machinery, in the management field 
which is a serious obstacle for SMEs and HR limitations, product development, production engineering, and product quality control.

\subsection{Quintuple Helix}

Quintuple helix is the application of knowledge from an innovation model that can overcome the challenges of global warming (Barth, 2011). Quintuple helix is a non-linear innovation model that combines knowledge and natural environmental systems into interdisciplinary and transdisciplinary to produce best and effective development, also restore the balance of nature (Carayannis \& Campbell, 2010).

The quintuple helix model is a theoretical and practical model as an exchange of knowledge sources (Carayannis \& Campbell, 2010). Quintuple helix through five subsystems consisting of academia, universities, higher education systems, industry, firms, economics systems, state, government, political systems, media based and culture based public, and natural environment, natural environments society.

From the perspective of developing and developed countries, Triple Helix is a physical device that successfully develops university-industry-government interactions that lead to the creation of companies, incubators, and science centers and the supporting movement for Academic Entrepreneurship (Safiullin, Fatkhiev, \& Grigorian, 2014). Triple helix can also increase the competitiveness of SMEs in Banyuwangi Regency (Susanti et all., 2020). But for networks that encourage the growth of creative industries in the city of Malang show an invisible role of academics so that it can only be called Double helix (Izzati \& Wilopo, 2018).

\section{Research Method}

This study uses a pre-test - post-test which is almost the same from experimental research (Creswell, 2012). The research was carried out by implementing the quintuple helix collaboration at CV. Kelorwangi Berkah Melimpah SMEs. Employees at CV. Employees at CV Kelorwangi Berkah Melimpah before training, pre-test is given to compare with post-test results after training. To obtain the results of the analysis of the pre-test and post-test data were analyzed using SPSS 20.0, to determine its effectiveness, a student test (t-test) was tested.

In order to improve the quality of the products produced, appropriate technology is applied to the results of university innovation, the role of consumers in developing products and social society to sustain business as in the quintuple helix.

\subsection{Population and Sample}

The population of this research is all employees of CV. Kelorwangi Berkah Melimpah, amounting to 10 people. The sample used is a total sampling (census) in which all members of the population are subject to research.

\subsection{Research Instrumens}

Data was taken before and after the implementation of quality control training from the results of the pre-test and post-test by giving essay essays to all employees of CV. Kelorwangi Berkah Melimpah. The results of pre-test and post-test were tested using paired sample t-test or paired sample $t$ test with valid provisions if significance $<0.025$. Paired sample $t$-test or paired sample t-test are two measurements of data on the same subject to a particular influence or treatment (Wiyono, 2011).

For the application of appropriate technology compared the number of defects and increased production capacity before and after the application of appropriate technology for 
pastry dough thinning. Media-based society is measured by an increase in the number of sales of Moringa processed products, while the natural environment is measured by the amount of supply of moringa raw materials from Moringa farmers

\section{Discussion}

Descriptive Analysis of the Pre-Test and Post-Test Quality Control Training result. The results of the descriptive analysis of the pre-test and post-test quality control training using SPSS 20 are shown in table 1 below:

Table 1. Results of Descriptive Analysis of Pre-Test and Post-Test Quality Control Training

\begin{tabular}{llllll}
\hline \multicolumn{2}{c}{ Paired Samples Statistics } & & \\
& & Mean & $N$ & $\begin{array}{l}\text { Std. } \\
\text { Deviation }\end{array}$ & $\begin{array}{l}\text { Std. Error } \\
\text { Mean }\end{array}$ \\
Pair & Pre_test & 67,90 & 10 & 10,461 & 3,308 \\
$\mathbf{1}$ & Post_test & 89,40 & 10 & 6,275 & 1,984
\end{tabular}

Table 1 shows the results of the descriptive analysis of quality control training before and after training. Test results showed an increase in the average pre-test and post-test results from 67.90 to 89.40 .

\subsection{Paired Sample T-Test Analysis Results}

1. Improvement in Average Ability of Participants in Statistical Quality Control

The results of the paired sample t-test analysis were conducted to determine the difference in average test values between before and after quality control training. The results of paired sample t-tests can be seen in Tables 2 and 3 below.

Tabel 2. Paired Samples Correlations

\begin{tabular}{|c|c|c|c|c|}
\hline \multicolumn{5}{|c|}{ Paired Samples Correlations } \\
\hline & & $\mathrm{N}$ & $\begin{array}{l}\text { Correlatio } \\
\mathrm{n}\end{array}$ & Sig. \\
\hline $\begin{array}{l}\text { Pair } \\
1\end{array}$ & $\begin{array}{l}\text { Pre_test \& } \\
\text { Post_test }\end{array}$ & 10 & ,693 &, 026 \\
\hline
\end{tabular}

The correlation value between the 2 variables is 0.885 , which means that the relationship is strong and positive. The significance level of the relationship is 0,000 , meaning that it is significant at the 0.05 level.

Tabel 3. Paired Samples Test

\begin{tabular}{|c|c|c|c|c|c|c|c|c|c|}
\hline \multicolumn{10}{|c|}{ Paired Samples Test } \\
\hline & & \multicolumn{5}{|c|}{ Paired Differences } & \multirow[t]{5}{*}{$\mathrm{t}$} & \multirow[t]{5}{*}{$\mathrm{f}$} & \multirow{5}{*}{$\begin{array}{l}\text { Sig. (2- } \\
\text { tailed) }\end{array}$} \\
\hline & & \multirow{4}{*}{ Mean } & \multirow{4}{*}{$\begin{array}{l}\text { Std. } \\
\text { Deviatio } \\
\mathrm{n}\end{array}$} & \multirow{4}{*}{$\begin{array}{l}\text { Std. } \\
\text { Error } \\
\text { Mean }\end{array}$} & \multirow{3}{*}{\multicolumn{2}{|c|}{$\begin{array}{l}95 \% \text { Confidence } \\
\text { Interval of the } \\
\text { Difference }\end{array}$}} & & & \\
\hline & & & & & & & & & \\
\hline & & & & & & & & & \\
\hline & & & & & Lower & Upper & & & \\
\hline Pair 1 & $\begin{array}{l}\text { Pre_test - } \\
\text { Post_test }\end{array}$ & $-21,500$ & 7,605 & 2,405 & $-26,940$ & $-16,060$ & $-8,940$ & 9 & ,000 \\
\hline
\end{tabular}

H0: There is no difference in average test scores between before and after training H1: There is a difference in average test scores between before and after training If Significance $<0.025$, Ho is rejected (Wiyono, 2011). 
Based on table 3 the significance value is 0.00 , so the significance $<0.025$ then Ho is rejected, meaning that there are differences in the average test scores between before and after training. This means, it can be concluded that employees who received quality control training differed in value from those who did not. The mean $-21,500$ is negative, it means there is a tendency to increase the ability after the training. The average increase is 21,500 .

\subsection{The Results of Applying Appropriate Technology the Moringa Leaf Flouring Machine and Moringa Stem Chopper Machine}

To improve the quality and capacity of the production of Moringa capsules produced, appropriate technology is applied to the machine of flour and chopper machine Moringa stem on the CV. Kelorwangi Berkah Melimpah.

With the usage of the flour machine, production capacity rose from $2 \mathrm{~kg}$ per day to 50 $\mathrm{kg}$ per day. Moringa stems that are not processed into flour are chopped and processed into Moringa tea. With the moringa stem chopper machine, the Moringa stem that has been discarded can reprocessed into Moringa tea.

\subsection{Media Based Society}

Moringa capsules were previously packaged in bottles and can be used to treat various diseases. Based on consumers impression, Moringa capsules are very useful for treating gout so that Moringa capsules are designed to be capsules for uric acid. With the change in packaging, sales of Moringa capsules increased from 100 bottles per month to 200 bottles per month.

\subsection{Natural Environment}

CV. Kelorwangi Berkah Melimpah has been partnering with Moringa farmers and housewives who use vacant land in the yard to plant Moringa plants. With this partnership, CV. Kelorwangi Berkah Melimpah add to the income of moringa farmers and mothers around CV. Kelorwangi Berkah Melimpah. The results achieved in this empowerment program are in line with what was delivered by (Omotesho, Fayeye, \& Babatunde, 2013) which states planting and use of Moringa trees by farmers can be a poverty alleviation program and is one of the tools for community development.

\subsection{Quintuple Helix Interaction in Developing SMES Competitiveness}

The interaction of quintuple helix in developing SMES competitiveness is described as follows:

\section{a. University}

The University has a role in the Tri Dharma College, namely Education, Research, and Community Service. in that role the University also plays a major role in the triple helix. In the field of education, the University plays a role in producing knowledge and disseminating knowledge. In the field of research, universities play a role in the spread of research and technology. In the field of community service, the University plays a role in the planning, socialization and dissemination stages of science (Fitriana, 2016).

Thus, universities can play a role in developing SMEs competitiveness:

a. In the field of education, the role is to help solve the problems faced by SMEs by generating and disseminating new knowledge.

b. In the field of research, the role is to provide alternative solutions in making policies about SMEs, generating innovations to solve problems which is faced by SMEs, both in terms of management and technology (Arnkil, 2010). 
c. In the field of community service, the role is to participate in the planning process, and solving SMES problems, expert consultants to overcome SMEs problems, and form business incubators (Fitriana, 2017) and play a role in the transfer of science and technology to business actors (Dzisah \& Etzkowitz, 2008).

\section{b. Industry}

Industry plays a role in creating entrepreneurship, products, technology, and as a booster of innovation (Fitriana, 2016). In addition, the industry also plays a role in management training, business coaching, mentoring, and forming communities as a means of sharing ideas (Fitriana, 2016). The role of industry in developing the competitiveness of SMEs is as a booster of industrial growth to be able to be highly competitive (Izzati \& Wilopo, 2018).

\section{c. Government}

The role of government in the triple helix according to Fitriana Fitriana (Fitriana, 2016) is as consumers, investors, and entrepreneurs, as regulators that produce policies relating to people, industry, intermediation, institutions, resources and technology, facilitators, catalysts, and provide stimulation, advocate, provide challenges and encouragement to improve business competence.

\section{d. Media Based Community}

The fourth subsystem, media-based and culture-based public, integrates and combines two forms of capital. On the one hand, this helix has an important role through culture-based society (for example: tradition, values, etc.), a social capital. On the other hand, public-based media helix (for example: television, internet, newspapers, etc.) also contain information capital (for example: news, communication, social networking) (Barth, 2011).

\section{e. Natural Environment}

The natural environment as the fifth subsystem is crucial for sustainable development and provides people with natural capital (for example: resources, plants, animal variations, etc.) (Barth, 2011). The effectiveness of the implementation of quintuple helix in developing SMEs competitiveness with Quintuple helix application in developing SMES competitiveness can be seen in Figure 1 below:

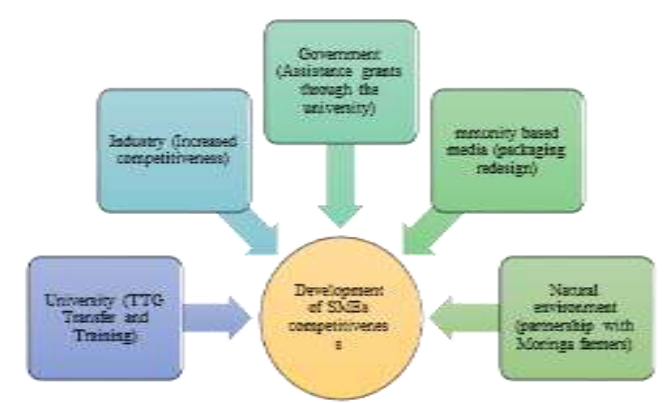

Figure 1. With Quintuple Helix Application in Developing SMES Competitiveness

\section{f. University}

In developing the competitiveness of SMEs, one of the roles of the university is to transfer approriate technology to the Moringa Powder Machine, Moringa Tea Sealer Machine, Crusser Machine for chopping Moringa Stems from University if 17 Agustus 1945 Banyuwangi to CV. Kelorwangi Berkah Melimpah and quality control training for all employees. In addition, assistance is also provided for business legality management, starting from the management of halal certification to the distribution permit at the Food and Drug Supervisory Agency (BPOM). The activity is the application of one of University's vows in the field of 
community service activities (Wisdaningrum et all., 2019), based on this matter to help reduce the defective products produced at CV. Kelorwangi Berkah Melimpah and to expand market reach by obtaining marketing authorization from BPOM.

\section{g. Industry}

One of the roles of CV. Kelorwangi Berkah Melimpah in developing SMES competitiveness is by encouraging other SMEs to be highly competitive. With the higher quality of products produced by CV. Kelorwangi Berkah Melimpah, it can improve the quality of the products produced to process Moringa flour into bath soap, Moringa tea and beauty masks so that it can be highly competitive.

\section{h. Government}

The government has a role in developing the competitiveness of SMEs, one of which is by providing grants through universities. Grants from the government are given through the Technology Based Starter Company (PPBT) program of the Directorate of Innovation of the Research Ministry and Higher Education through the business incubator of the University of 17 August, 1945 Banyuwangi which is trusted to assist tenants who have innovations, one of which is CV. Kelorwangi Berkah Melimpah. which has an innovation in processing Moringa into capsules and Moringa tea.

\section{i. Media Based Community}

Media-based society plays a role in providing suggestion for packaging redesign. By paying attention to the suggestions and idea from the media based community which in this case is a consumer of processed Moringa products stated that Moringa capsules can cure gout. Based on it, CV. Kelorwangi Berkah Melimpah redesigned the packaging with the name of "Kelorat" which is identical to Moringa for gout.

\section{j. Natural Environment}

For the sustainability of Moringa supply, CV. Kelorwangi Berkah Melimpah partnered with Moringa farmers and housewives who used vacant land in the yard to plant Moringa plantations. With this partnership, CV. Kelorwangi Berkah Melimpah increase the income of moringa farmers and ladies around CV. Kelorwangi Berkah Melimpah.

Intellectual support must come from universities or institutions of higher education that conduct research and / or skilled workers and applicable knowledge (Dzisah \& Etzkowitz, 2008). Meanwhile Holgaard (Holgaard, 2012) proves that civil society, as users of goods and services, plays an important role in lifestyle, consumption behavior, and social institutional participation. Industry facilitates business incubators, technopark science, and knowledge commercialization to help companies meet their goals (Ranga \& Garzik, 2015). Civil society based on culture and media must formally contribute to bottom-up participation (Yawson, 2012).

Research (Simon, Houghton, \& Aquino, 2000) that the development of innovative products is important for small industries. To satisfy customers, small industries must develop high quality product offerings that meet the needs and desires of consumers. (Keh, Nguyen, \& $\mathrm{Ng}, 2007)$ states that innovation is very important because of rapid technological changes, shorter product life cycles, and new consumers are more informed and increasingly smart, requiring the fulfillment of consumer needs with high quality products and added value through propositions superior value. Research (Rosli Mahmood et al., 2013) and (Salim \& Sulaiman, 2011) also suggest that innovation and creativity can improve organizational 
performance, and refer to the innovation process in small and medium sized companies that have a significant influence on company performance (Rosli \& Sidek, 2013).

Collaboration of University, industry, government, media-based society, and natural environment (quantiple helix) in the development of SMEs so that high competitiveness is applied in the CV. Kelorwangi Berkah Melimpah, then it can:

1. Improving the ability of human resources in the CV. Kelorwangi Berkah Melimpah through quality control training

2. Increase production capacity

3. Increase UMKM sales profit

4. Increase partner income as a supplier of raw materials

\section{Conclusion}

1. To develop SMEs competitiveness, university, industry, government, media-based society and natural environment (quintuple helix) synergy is needed.

2. With the synergy of the university, industry, government, media-based society, and the natural environment (quintuple helix) can improve the ability of human resources, improve the quality, and competitiveness of products produced by SMEs.

\section{References}

Abrhám, J., Bilan, Y., Krauchenia, A., \& Strielkowski, W. (2015). Planning horizon in labour supply of Belarusian small entrepreneurs. Economic Research-Ekonomska Istraživanja, 28(1), 773-787. https://doi.org/10.1080/1331677X.2015.1084238.

Arnkil, R. et al. (2010). Exploring Quadruple Helix Outlining user-oriented innovation models Final. In Tampere: The CLIQ. Retrieved from http://www.arnkildialogues.com/files/testataan.kotisivukone.com/julkaisut/exploring _quadruple_helix-2010-1.pdf.

Barkhatov, V., Pletnev, D., \& Campa, A. (2016). Key Success Factors and Barriers for Small Businesses: Comparative Analysis. Procedia - Social and Behavioral Sciences, 221, 29-38. https://doi.org/10.1016/j.sbspro.2016.05.087.

Barth, T. D. (2011). The idea of a green new deal in a Quintuple Helix Model of knowledge, know-how and innovation. International Journal of Social Ecology and Sustainable Development, 2(1), 1-14. https://doi.org/10.4018/jsesd.2011010101.

Belás, J., Bilan, Y., Demjan, V., \& Sipko, J. (2015). Entrepreneurship in sme segment: Case study from the Czech Republic and Slovakia. Amfiteatru Economic, 17(38), 308-326. Retrieved from http://www.amfiteatrueconomic.ro/temp/Article_2387.pdf.

Berg, H. Van den. (2012). Economic Growth and Development (2nd ed.). USA: University of Nebraska..

Brilhante, R. S. N., Sales, J. A., Pereira, V. S., Castelo-Branco, D. de S. C. M., Cordeiro, R. de A., de Souza Sampaio, C. M., ... Rocha, M. F. G. (2017). Research advances on the multiple uses of Moringa oleifera: A sustainable alternative for socially neglected population. Asian Pacific Journal of Tropical Medicine, 10(7), 621-630. https://doi.org/10.1016/j.apjtm.2017.07.002.

Carayannis, E. G., Barth, T. D., \& Campbell, D. F. (2012). The Quintuple Helix innovation model: global warming as a challenge and driver for innovation. Journal of Innovation and Entrepreneurship, 1(1), 2. https://doi.org/10.1186/2192-5372-1-2.

Carayannis, E. G., \& Campbell, D. F. J. (2010). Triple helix, Quadruple helix and Quintuple helix and how do Knowledge, Innovation and the Environment relate to Each other? a proposed framework for a trans-disciplinary analysis of sustainable development and 
social ecology. International Journal of Social Ecology and Sustainable Development, 1(1), $41-$ 69. https://doi.org/10.4018/jsesd.2010010105.

Creswell, J. W. (2012). Education Research, Planning, Conducting and Evaluating Quantitative and Qualitative Research (4th ed.). Boston: Pearson.

Dzisah, J., \& Etzkowitz, H. (2008). Triple helix circulation: the heart of innovation and development. International Journal of Technology Management and Sustainable Development, 7(2), 101-115. https://doi.org/10.1386/ijtm.7.2.101_1.

Etzkowitz, H., \& Leydesdorff, L. (2000). The dynamics of innovation: From National Systems and "mode 2" to a Triple Helix of university-industry-government relations. Research Policy, 29(2), 109-123. https://doi.org/10.1016/S0048-7333(99)00055-4.

Etzkowitz, H., \& Zhou, C. (2007). Regional innovation initia tor: the entrepreneurial unive rsity in various triple helix models. Singapore Triple Helix VI Conference Theme Paper, (July 2015), 1-25. Retrieved from http://nus.edu/nec/eir/TripleHelix6/SingaporeConferenceThemePaper050107.pdf

Fitriana, W. (2016). Triple Helix Models for Agro-Tourism Development in West Sumatra. International Conference on Business, Economics, Socio-Culture and Tourism. In Online Proceedings, 1-556. Semarang: Economics Faculty.

Fitriana, W. (2017). The Role of Triple Helix Actors for Agro-Tourism Development in West Sumatera. MIMBAR, Jurnal Sosial Dan Pembangunan, 33(2), 219-227. https://doi.org/10.29313/mimbar.v33i2.2098.

Holgaard, Y. Y. and J. E. (2012). The important role of civil society groups in eco-innovation: a triple helix perspective. The Eletronic Library, 4(3), 132-148. https://doi.org/10.1108/17561411211235730.

Izzati, M. F., \& Wilopo. (2018). Implementasi Triple Helix Dalam Mendorong Pertumbuhan Daya Saing Untuk Menghadapi Masyarakat Ekonomi Asean. Jurnal Administrasi Bisnis, 55(1), 59-68. Retrieved from http://journal.lembagakita.org/index.php/emt/article/download/20.

Janda, K., Rausser, G., \& Strielkowski, W. (2013). Determinants of profitability of polish rural micro-enterprises at the time of EU accession. Eastern European Countryside, 19(1), $177-$ 217. https://doi.org/10.2478/eec-2013-0009.

Keh, H. T., Nguyen, T. T. M., \& Ng, H. P. (2007). The effects of entrepreneurial orientation and marketing information on the performance of SMEs. Journal of Business Venturing, 22(4), 592-611. https://doi.org/10.1016/j.jbusvent.2006.05.003.

Koudelková, P., \& Svobodová, A. (2014). Knowledge Creation \& Sharing as Essential Determinants of SMES Innovation. International Economics Letters, 3(1), 12-20.

Omotesho, K. F., Fayeye, T. R., \& Babatunde, R. O. (2013). The potential of Moringa tree for poverty alleviation and rural development: Review of evidences on usage and efficacy. International Journal of Development and Sustainability, 2(2), 799-813.

Pletnev, D., \& Barkhatov, V. (2016). Business Success of Small and Medium Sized Enterprises in Russia and Social Responsibility of Managers. Procedia - Social and Behavioral Sciences, 221, 185-193. https://doi.org/10.1016/j.sbspro.2016.05.105.

Praswati, A. N. (2017). Perkembangan Model Helix Dalam Peningkatan Inovasi. Seminar Nasional Riset Manajemen \& Bisinis: Perkembangan Konsep Dan Riset E-Business Di Indonesia, 690-705. Retrieved from https://publikasiilmiah.ums.ac.id/handle/11617/9022.

Ranga, M., \& Garzik, L. (2015). From Mozart to Schumpeter: A Triple Helix Systems approach to advancing regional innovation in the Salzburg region of Austria. In: Austrian Council for Research and Technology Development. Designing the Future: Economic, Societal and Political Dimensions of Innovation, (August), 244-300.

Rosli, M. M., \& Sidek, S. (2013). The Impact of Innovation on the Performance of Small and Medium Manufacturing Enterprises: Evidence from Malaysia. Journal of Innovation 
Management in Small \& Medium Enterprise, pp. 1-16. https://doi.org/10.5171/2013.885666.

Rosli Mahmood, Mahmood, R., Aarakit, S. M., Alarape, A. A., Al-swidi, A. K., Al-Hosam, A., ... Me, N. (2013). Entrepreneurial orientation and business performance of womenowned small and medium enterprises in Malaysia: Competitive advantage as a mediator. International Journal of Business and Social Science, 4(1), 82-90. https://doi.org/10.1177/0266242612455034.

Safiullin, L. N., Fatkhiev, A. M., \& Grigorian, K. A. (2014). The Triple Helix Model of Innovation. Mediterranean Journal of Social Sciences, 5(18), 203-206. https://doi.org/10.5901/mjss.2014.v5n18p203.

Salim, I. M., \& Sulaiman, M. (2011). Organizational Learning, Innovation and Performance: A Study of Malaysian Small and Medium Sized Enterprises. International Journal of Business and Management, 6(12), 118. https://doi.org/10.5539/ijbm.v6n12p118.

Simionescu, M., Bilan, Y., Smrčka, L., \& Vincúrová, Z. (2017). The Effects of European Economic Integration and the Impact of Brexit on the UK Immigrants from the CEE Countries. E a M: Ekonomie a Management, 20(1), 29-46. https://doi.org/10.15240/tul/001/2017-1-003.

Simon, M., Houghton, S. M., \& Aquino, K. (2000). Cognitive biases, risk perception, and venture formation: How individuals decide to start companies. Journal of Business Venturing, 15(2), 113-134. https://doi.org/10.1016/S0883-9026(98)00003-2.

Susanti et all. (2020). Triple Helix Synergy for Development and Enhancing Competitiveness of SMEs. Britain International of Humanities and Social Sciences (BIoHS) Journal, 2(1), 321327. https://doi.org/10.33258/biohs.v2i1.195.

Trisnawati. (2016). Kajian Inovasi Sektor Usaha Kecil Menengah ( UKM) dengan Pendekatan Sistem Dinamis ( Studi Kasus pada Industri Makanan di Kabupaten Sidoarjo Jawa Timur ). Jurnal Akuntansi, Ekonomi Dan Manajemen Bisnis, 4(1), 60-67. Retrieved from https://jurnal.polibatam.ac.id/index.php/JAEMB/article/view/86/78.

Undang-Undang No 20 Tahun 2008 (pp. 1-31). (2008). Retrieved from https://www.bi.go.id/id/tentang-bi/uu-bi/Documents/UU20Tahun2008UMKM.pdf

Varanavicius, V., Navikaite, A., Bilan, Y., \& Strielkowski, W. (2017). Analysis Of Consumer Behaviour In Regional Energy Consumption. Regional Energy Consumption. Ekonomika Regiona [Economy of Region], 13(1), 137-146. https://doi.org/10.17059/2017.

Wahyuningrum, P., Sukmawati, A., \& Kartika, L. (2014). Peningkatan Kinerja Usaha Kecil dan Menengah (UKM) Kluster Kerajinan di Kota Depok Menggunakan The House Model. Jurnal Manajemen Dan Organisasi, 5(2), 154-166. https://doi.org/10.29244/jmo.v5i2.12156.

Wisdaningrum et all. (2019). Program Kemitraan Masyarakat (PKM) Kue Kering Pastrikacang Di Kabupaten Banyuwangi. Seminar Nasional Sistem Informasi, Fakultas Teknologi Informasi - UNMER Malang, 1673-1681. Retrieved from https://jurnalfti.unmer.ac.id/index.php/senasif/article/download/229/189/

Wiyono, G. (2011). Merancang penelitian bisnis dengan alat analisis SPSS 17.0 \& SmartPLS 2.0 (Pertama). Yogyakarta: UPP STIM YKPN.

Yawson, R. M. (2012). The Ecological System of Innovation: A New Architectural Framework for a Functional Evidence-Based Platform for Science and Innovation Policy. SSRN Electronic Journal, 1-16. https://doi.org/10.2139/ssm.1417676. 